\title{
The Priorities for EU Tax Policy
}

\section{The main challenges}

In the Day Away of the European Union (EU) Platform for Tax Good Governance, digitalization of the economy, climate change, ageing, and unanimity in taxes were identified as the main challenges for the future of corporate income tax and other income tax, as well as regulatory taxes in Europe. The Platform is meant to represent different relevant players and sensitivities in the choices for EU tax policy, ${ }^{1}$ and the meeting took place a few days before the EU Parliamentary elections last 26 May.

Some awareness about the ongoing changes is illustrated by the selected answers to the Slido.com questionnaire used by the European Commission in the meeting. $84 \%$ of the respondent Platform Members held that the composition of the EU Member States' tax revenues will not be the same in fifteen years. Both corporate income tax $(43 \%)$ and environmental taxes $(39 \%)$ were chosen as the biggest challenges for tax reform.

However, the above-mentioned awareness contrasts with the lack of ambition by peers, and some blindness in respect of the required coordination and consensus were also revealed in the polls:

$73 \%$ of the participants held that current tax policies in the EU are being designed with future challenges and evolutions in mind; $23 \%$ voted 'not at all'; and 5\% voted 'sufficiently'.

\section{TAXES IN FIFTEEN YeARS AND A MINIMUM LEVEL OF TAXATION}

'Future Trends and Taxation' was 'The Scene Setter' of the above-mentioned Platform meeting. One of the highlights was climate change and the fact that it is already affecting tax revenues and public expenditure in Europe due to the increasing need to use national and EU taxes to fight against natural catastrophes. Climate change and the emerging climate-friendly economy raises the issue on whether taxes shall have a regulatory function - according to the polluter-payer principle, as mentioned by our guest editor, Valère Mourtalier - or whether it is preferable to directly regulate the economy.

A perception by tax authorities seems to exist that both climate change and the digital economy require coordination, but it is not so clear whether this means European or international coordination. This hesitation in the EU together with the difficulty of finding consensus in the international landscape is leading to different tax bases and rates in domestic taxes that are moved by fiscal and extra fiscal purposes other than efficiency. The fact that the climate is an international public good would require the same tax per unit of emissions for everyone everywhere.

Interestingly, ageing might bring a difference in Europe, reinforcing the need of coordination and harmonization: taken altogether, advances in Artificial Intelligence and Robotics, climate change, and ageing will have a long-term negative impact on income equality, income tax bases, and tax revenues. This raises the issue of limiting income tax competition by replacing it with a different tax or complementing it with several taxes with regulatory and fiscal purposes but, in the case of the latter, with acknowledged distortionary effects.

It is clear, however, that introducing a minimum level of tax in the EU territory would lead to relocation of capital to third States. Moreover, the Anti-Tax Avoidance Directive CFC rules target companies without substantive economic activity or non-genuine arrangements ${ }^{2}$ and may prevent a decrease of tax rates that are applicable to intangibles, services, passive income, and other non-materialized activities but will not avoid a decrease of rates in brick and mortar businesses.

This could justify the recent OECD proposals on a minimum level of tax. The proposal 'seeks to address the

\section{Notes}

European Commission, Platform for Tax Good Governance, https://ec.europa.eu/taxation_customs/business/company-tax/tax-good-governance/platform-tax-good-governance_ en (accessed 24 June 2019).

2 See Art. 7(2) of the Council Directive (EU) 2016/1164 of 12 July 2016 Laying down Rules against Tax Avoidance Practices that Directly Affect the Functioning of the Internal Market, OJ L 193/1 (19 July 2016). 
remaining BEPS challenges through the development of two inter-related rules:

(1) an income inclusion rule that would tax the income of a foreign branch or a controlled entity if that income was subject to a low effective tax rate in the jurisdiction of establishment or residence; and

(2) a tax on base eroding payments that would deny a deduction or treaty relief for certain payments unless that payment was subject to an effective tax rate at or above a minimum rate'. ${ }^{3}$

This proposal builds on the 'fair tax competition' criterion that is part of the EU External strategy on tax good governance and the Code of Conduct on Business Taxation Criteria, which is included in the EU Anti-Tax Avoidance Package. The 'fair tax competition' criterion requires a minimum level of taxation in third countries, ${ }^{4}$ contributing to international coordination and preventing capital outflow from the EU:

\section{FAIR TAX COMPETITION}

Fair tax competition means that a third country should not operate harmful tax measures in the area of business taxation. Tax measures which provide for a significantly lower effective level of taxation, including zero taxation, than those levels which generally apply in the third country in question are to be regarded as potentially harmful. Such a significantly lower level of taxation may operate by virtue of the nominal tax rate, the tax base or any other relevant factor.

When assessing whether such measures are harmful, account should be taken of the criteria as provided for in the Code of Conduct on Business Taxation endorsed by the Council, as well as practice and guidance agreed by the Code of Council working group.

The OECD proposal is a switchover mechanism targeting both residence and source jurisdictions and, in this way, it is more balanced than the unilateral EU fair tax competition standard.

However, there will be no consensus on what is a 'low effective tax rate' or 'a significantly lower effective level of taxation, including zero taxation, than those levels which generally apply in the third country'. Thus, the criticism I raised before to the EU 'fair tax competition' criterion ${ }^{5}$ that included a paradoxal effect of race-to-the-bottom is valid in respect of this OECD proposal.

Moreover, if this proposal would be adopted unilaterally, the different meaning of a 'low effective tax rate' in each jurisdiction would still lead to tax competition.

Although tax competition is a serious problem that may lead to a sustainability gap in the European Union, a minimum level of taxation will hardly be achieved in the absence of EU taxes (or an international entity and budget).

The selection of tax policy priorities is close to the priorities discussed by all Spitzenkandidaten for the European Commission President (with the exception of ageing) ${ }^{6}$ and the rise of the liberals and the greens in the European Parliament elections. Tax policy makers - both national and the EU - should seriously interpret the results for the EU Parliament elections as a mandate to make competitiveness (innovation) and policies facing climate change compatible. The adoption of a qualified majority for the harmonization of taxes with sunset clauses would mean more flexibility in the EU tax policy and, therefore, contribute to innovation and adequate climate change policies.

\section{IN THIS ISSUE}

In this issue, our guest-editorial by Valère Mourtalier draws a balance on the five years of EU tax policy, characterizing it as the most dynamic period of EU tax policy. Mourtalier makes reference to the new tax transparency framework, the Directives on Administrative Cooperation, the Anti-Tax Avoidance Directives, the work done by the Code of Conduct on Business Taxation, the EU list of non-cooperative jurisdictions, and the Double Taxation Dispute Resolution Mechanism. Mourtalier also focuses on the future Commission mandate of five years, highlighting the need to move towards a qualified majority in taxes, to further work on the digital economy and taxes, the role of taxes on energy and climate change, and the need for a simpler and more stable tax landscape.

The articles published in this issue focus on varied topics:

Gianluca Mazzoni published an interesting research work on the League of Nations' minutes of meetings from 1923 to 1928 that is aimed at finding the origins of the single tax principle; Tatiana Falcão's article focuses on Taxing Carbon Emissions from International Shipping;

\section{Notes}

OECD, Public Consultation Document Addressing the Tax Challenges of the Digitalisation of the Economy, Base Erosion and Profit Shifting Project (OECD Publishing, 13 Feb.-6 Mar. 2019), http://www.oecd.org/tax/beps/public-consultation-document-addressing-the-tax-challenges-of-the-digitalisation-of-the-economy.pdf (accessed 24 June 2019 ).

4 European Commission, Communication from the Commission to the European Parliament and the Council on an External Strategy for Effective Taxation, COM (2016) 24 final (28 Jan. 2016). See A. P. Dourado, The EU Anti Tax Avoidance Package: Moving Abead of BEPS, 44(6/7) Intertax $440-46$ (2016).

See Dourado, supra n. 4, at 441.

6 YouTube, Full 2019 Spitzenkandidaten debate at the European Parliament (17 May 2019), https://www.youtube.com/watch?v=IzCa_T8BZVI (accessed 24 June 2019). 
Ivan Lazarov and Sriram Govind discuss the validity of the Anti-Tax Avoidance Directives in Light of EU Law; Antonio Cuoco examines the Principal Purpose Test as introduced by the Multilateral Instrument and its compatibility with EU Law.

The reader may also find: Two case law notes, one by Robert F. van Brederode on the South Dacota v. Wayfair Inc. at al. Case ('The Future of the Economic Nexus Standard for U.S. Sales \& Use Tax Collection') another by Sebastian Kirsch and Carloline Orban on the Vega International Case; and two literature reviews including one by Roman Seer on Xavier Oberson's book
'International Exchange of Information in Tax Matters' and another by Cristina Trenta on Jasmin Kollman's book 'Taxable Supplies and Their Consideration in European VAT' that is based on her research work 'Taxable Supplies and their Consideration in European VAT General Theory and Selected Issues of the Digital Economy - A Need for a New Set of Rule?', which was awarded the IFA Maurice Lauré Prize in $2018 .^{7}$

$$
\text { Ana Paula Dourado }
$$

General Editor

EATLP Member for the EU Platform on Tax Good Governance. Email: anadourado@fd.ulisboa.pt

\section{Notes}

7 International Fiscal Association, Maurice Lauré Prize, https://www.ifa.nl/research-awards/maurice-lauré-prize (accessed 24 June 2019 ). 